University of Thi-Qar Journal Vol.12 No.4 DEC 2017

Web Site: https://jutq.utq.edu.iq/index.php/main

Email: journal@jutq.utq.edu.iq

\title{
A Correlation of Adenosine Deaminase Activity with Calcium \\ Concentration in Sera of Renal Failure Patients \\ https://doi.org/10.32792/utq/uti/vol12/4/1
}

\section{Ali Haneen Issmer* \\ Dept. of Chemistry, College of Science, University of Thi-Qar}

\begin{abstract}
Chronic renal failure (CRF) is one of the major public health problems in Iraq. This work aimed to investigate whether adenosine deaminase (ADA) activity has any correlation with calcium concentration in patients with CRF for the first time, then using this correlation as a diagnostic tool for CRF disease. Creatinine $(\mathrm{Cr})$, urea, total protein concentrations, in addition to ADA activity and calcium concentration, were measured for 33 males individuals divided to two groups, the first group included eighteen patients with CRF before hemodialysis at department of artificial kidney of Al-Hussein Teaching Hospital in Thi-Qar (Iraq) while control group included fifteen healthy matched individuals. The results showed that a significant increase in $\mathrm{Cr}$, urea concentrations in addition to ADA activity, while there was a significant decrease in a total protein and calcium concentrations for patients group comprised with control group $(\mathrm{p}<0.05)$. Indeed, there was a weak negative correlation between ADA activity and calcium concentration according to this study.
\end{abstract}

Keywords: Adenosine deaminase, chronic renal failure, calcium concentration.

\section{Introduction}

Kidney diseases are a public health problem worldwide. In Iraq, over recent years, there has been a significant rise in the number of patients with chronic renal failure (CRF), where there is increased number of patients 


\section{University of Thi-Qar Journal Vol.12 No.4 DEC 2017 \\ Web Site: https://jutq.utq.edu.iq/index.php/main \\ Email: journal@jutq.utq.edu.iq}

undergoing dialysis to keep their life. Unfortunately, there is no official data about Iraqi patients with renal failure either on website of Iraqi ministry of health, nor world health organization (WHO) databases related Iraq state. But some of official statements mentioned there were 20 patients per day admitted to department of artificial kidney in Al-Hussein Teaching Hospital, in Thi-Qar province (Iraq) in order to carry out dialysis [1].

Abbreviations: ADA: adenosine deaminase. CRF: chronic renal failure. Cr: creatinine., TP: total protein.

- Corresponding author: alihaneen77@gmail.com

The renal failure refers to a condition where the kidneys lose their normal function due to various factors resulting accumulation of waste and toxic materials inside the body such as urea and creatinine $(\mathrm{Cr})$, therefore tests of urea and $\mathrm{Cr}$ are sufficient tests to evaluate whether a patient is suffering kidney disease, in addition to follow-up of control and treatment of this disease $[2,3]$.

Acute and chronic renal failure are the two types of renal failure. And some factors which may help differentiate these types of kidney diseases include the presence of anemia and the kidney size on ultrasound [4]. Chronic renal failure (CRF) is defined as an abnormal low glomerular filtration rates (GFR) due to slowly progressive loss of kidney function over a long period [5]. In general, CRF leads to anemia and small kidney size [6]. When the kidneys lose about (85-90) \% of its function, meaning that end stage kidney failure had done, thus the dialysis is needed [5]. Dialysis is one of the renal replacement therapy, during which waste products, such as creatinine, urea and excess water, are removed from body [4]. 


\section{University of Thi-Qar Journal Vol.12 No.4 DEC 2017 \\ Web Site: https://jutq.utq.edu.iq/index.php/main \\ Email: journal@jutq.utq.edu.iq}

Adenosine deaminase (ADA) ( EC.3.5.4.4) is one of purine metabolic enzyme which is play a major role in irreversible hydrolytic deamination of both adenosine and 2'-deoxyadenosine to inosine and 2'-deoxyinosine, respectively, the step which is an essential in the adenosine cycle, and a part of the purine salvage pathway $[7,8]$.

ADA is widely distributed in many tissues, especially in small intestine, liver and kidney. Many studies had report the effect of this enzyme deficiency on the immune system and it used as a marker for assessment of cell-mediated immunity in man $[9,10]$. There are two major principals ADA isoenzymes: ADA1 and ADA2, which differ in optimal $\mathrm{pH}$, Michaelis constants as well as relative substrate specificity frames. ADA2 is the predominant isoenzyme in the sera in all infectious diseases. High total activity of ADA that is reported in many pathological states is due to high activity of ADA2 isoenzyme [11].

ADA is located mainly in cytosol, and also can be considered as an ectoenzyme because it found on the cell surface of many cell types. It has important role in different metabolic and pathological conditions, such as the intra renal metabolic regulation of kidney function [8].

The kidneys play an essential role in calcium metabolism and patients with CKD have low blood calcium levels [12]. It is worth to be mentioned that few previous studies which interested ADA in renal failure patients but they never enlighten a correlation of ADA and calcium $[3,6]$. The objective of this study is trying to find early diagnostic tool for this disease and monitor steps of treatment via investigation whether adenosine deaminase (ADA) activity has any correlation with calcium concentration in patients with (CRF) for the first time. 


\section{University of Thi-Qar Journal Vol.12 No.4 DEC 2017}

Web Site: https://jutq.utq.edu.iq/index.php/main

Email: journal@jutq.utq.edu.iq

\section{Materials and methods:}

\subsection{Patients}

This study included eighteen males patients (Age $=40-70$ years) suffering CRF and admitted to department of artificial kidney of Al-Hussein Teaching Hospital, in Thi-Qar (Iraq). Also fifteen healthy-looking individuals (age, sex matched) had been selected as a control group to compare with our patients in the same parameters of this study.

\subsection{Samples collection:}

Five milliliters of venous blood was taken from each patient and left for (30) minutes at room temperature for coagulation, sera then were separated by centrifugation at (3000 rpm) for (10) min and used in the same day for calcium assay, and stored in caped sterilized tubes at (-20) $\mathrm{C}$ until time of used for other assays.

\subsection{Determination of urea and creatinine concentrations:}

As a standard tools for CRF diagnosis, both urea and creatinine concentrations were estimated using kits provided by biomerieux company (France).

\subsection{Adenosine deaminase activity assay}

The activity was determined in the serum according to the method of Giusti with slight modification in order to prepare the reagents with volumes less than volumes which were mentioned in the reference [13]. All reagents were prepared from analar grade laboratory chemicals from the companies: BDH, Fluka, and Hopkins \& williames. To avoid loss or gain of ammonia in these reagents which may interfere with the results, they were prepared at the time of assay initiation. The reagents were prepared as a following:

R1: Phosphate Buffer $(\mathrm{pH}=6.5,0.05 \mathrm{M})$ : 


\section{University of Thi-Qar Journal Vol.12 No.4 DEC 2017 \\ Web Site: https://jutq.utq.edu.iq/index.php/main Email: journal@jutq.utq.edu.iq}

About (4.73) g of hydrated sodium dihydrogen phosphate and (5.62) g of hydrated disodium hydrogen phosphate were dissolved in (90) $\mathrm{ml}$ of warm deionized water, then adjusting the $\mathrm{pH}$ to 6.5 with phosphoric acid, complete the final volume to (100) $\mathrm{ml}$ with warm deionized water.

R2: Buffered Adenosine Solution (0.021 M Adenosine, $\mathrm{pH}=6.5$ )

A weight of (0.0561) g of Adenosine was dissolved in R1, then the volume was made up to (10) $\mathrm{ml}$ with same solvent.

R3: Stock Solution of Ammonium Sulphate (0.015 M):

A weight of (0.1982) $\mathrm{g}$ of anhydrous ammonium sulphate was dissolved in (100) $\mathrm{ml}$ deionized water.

R4: Standard Solution of Ammonium Sulphate $(75 \mu \mathrm{M})$ :

About (250) $\mu$ l of $\mathbf{R 3}$ was diluted with $\mathbf{R} 1$ to (50) $\mathrm{ml}$.

R5: Nitroprusside/ Phenol Solution (0.17 mM Sodium Nitroprusside, 106 mM Phenol):

A weight of (5) g of sodium nitroprusside and (1) $g$ of phenol were dissolved in deionized water and volume was completed to (100) $\mathrm{ml}$ with the solvent.

R6: Alkaline Hypochlorite Solution (11mM NaOCl; $125 \mathrm{mM} \mathrm{NaOH})$ :

About (1.64) $\mathrm{ml}$ of sodium hypochlorite (5\% w/v) added to (12.5) $\mathrm{ml}$ of $1 \mathrm{~N}$ sodium hydroxide solution then bringing the final volume to (100) $\mathrm{ml}$ with deionized water.

Assay system was doing in duplicate as a following:

\begin{tabular}{|c|c|c|c|c|c|}
\hline & \multicolumn{5}{|c|}{ Tubes } \\
\hline Reagents & $\mathbf{R} \mathbf{b}^{*}(\mu \mathrm{l})$ & $\mathbf{S t}^{* *}(\mu \mathrm{l})$ & $\mathbf{A b} \cdot(\mu \mathrm{l})$ & $\mathbf{S b} \dagger(\mu \mathrm{l})$ & $S \neq(\mu l)$ \\
\hline R1 & 500 & 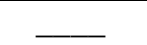 & 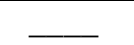 & 500 & $\ldots$ \\
\hline $\mathrm{R} 2$ & - & - & 500 & - & 500 \\
\hline $\mathrm{R} 4$ & 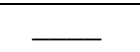 & 500 & $\ldots$ & - & $\ldots$ \\
\hline Sample (Serum) & 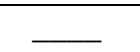 & L & - & 250 & 250 \\
\hline Deionized water & 250 & 250 & 250 & & \\
\hline
\end{tabular}

St: Sample 


\section{University of Thi-Qar Journal Vol.12 No.4 DEC 2017 \\ Web Site: https://jutq.utq.edu.iq/index.php/main \\ Email: journal@jutq.utq.edu.iq}

Each tube was mixed and stoppered with parafilm then incubated for (60) min in a $37{ }^{\circ} \mathrm{C}$ water bath, then to each tube, with vortex, (1.5) $\mathrm{ml}$ of $\mathbf{R 5}$ solution and (1.5) $\mathrm{ml}$ of $\mathbf{R 6}$ solution were added, further incubation for (30) min in a $37{ }^{\circ} \mathrm{C}$ water bath was carried out, then the absorbance at (628) nm was read using spectrophotometer for each tube against water.

\section{Calculations}

The enzyme activity was calculated according to the following equation :

$$
\text { Activity (U/L) }=\frac{a-b}{c} \times \frac{1}{t} \times \frac{1}{V_{s}} \times \frac{V_{I}}{V_{t}} \times 1000
$$

Where:

$$
\mathbf{a}=\mathrm{A}_{\mathrm{S}}-\mathrm{A}_{\mathrm{Sb}} ; \mathbf{b}=\mathrm{A}_{\mathrm{Ab}}-\mathrm{A}_{\mathrm{Rb}} ; \mathbf{c}=\mathrm{A}_{\mathrm{St}}-\mathrm{A}_{\mathrm{Rb}} ; \mathrm{t}=\text { Incubation time; } \mathrm{Vs}_{\mathrm{s}}=
$$
sample volume; $\mathrm{V}_{\mathrm{I}}=$ Incubation volume; $\mathrm{Vt}=$ total volume

For the assay, the values were as following:

$$
\begin{aligned}
& \text { Enzyme activity }(\mathrm{U} / \mathrm{L})=\frac{a-b}{c} \times \frac{1}{60} \times \frac{1}{0.025} \times \frac{0.525}{3.55} \times 1000 \\
& \text { Specific activity }(\mathrm{U} / \mathrm{mg})=\frac{\text { Enzyme activity }(\mathrm{U} / \mathrm{ml})}{\text { Total protein Conc. }\left(\frac{\mathrm{mg}}{\mathrm{ml}}\right)}
\end{aligned}
$$

\subsection{Determination of TP concentration:}

Total protein (TP) concentration was measured in all samples by using Biolabo kit company (France). According to Biuret method, the peptide bonds of proteins react with $\mathrm{Cu}^{2+}$ in alkaline solution to form colored complex which absorbance is measured at $550 \mathrm{~nm}$.

\subsection{Determination of calcium concentration:}

Calcium concentration was measured in all samples by using Biolabo kit company (France). 


\section{University of Thi-Qar Journal Vol.12 No.4 DEC 2017 \\ Web Site: https://jutq.utq.edu.iq/index.php/main \\ Email: journal@jutq.utq.edu.iq}

\section{Statistical Analysis}

Microsoft Excel program 2010 was used to analyze data in this study. All values were expressed as mean \pm standard deviation (SD). The differences were considered significant

when the probability ( $p$ value) was less than $0.05(p<0.05)$. the $p$ value was calculated using Student's T-test.

\section{Results and discussion:}

All obtained laboratory values are represented in table 1 .

Table 1: Laboratory findings of the two studied groups

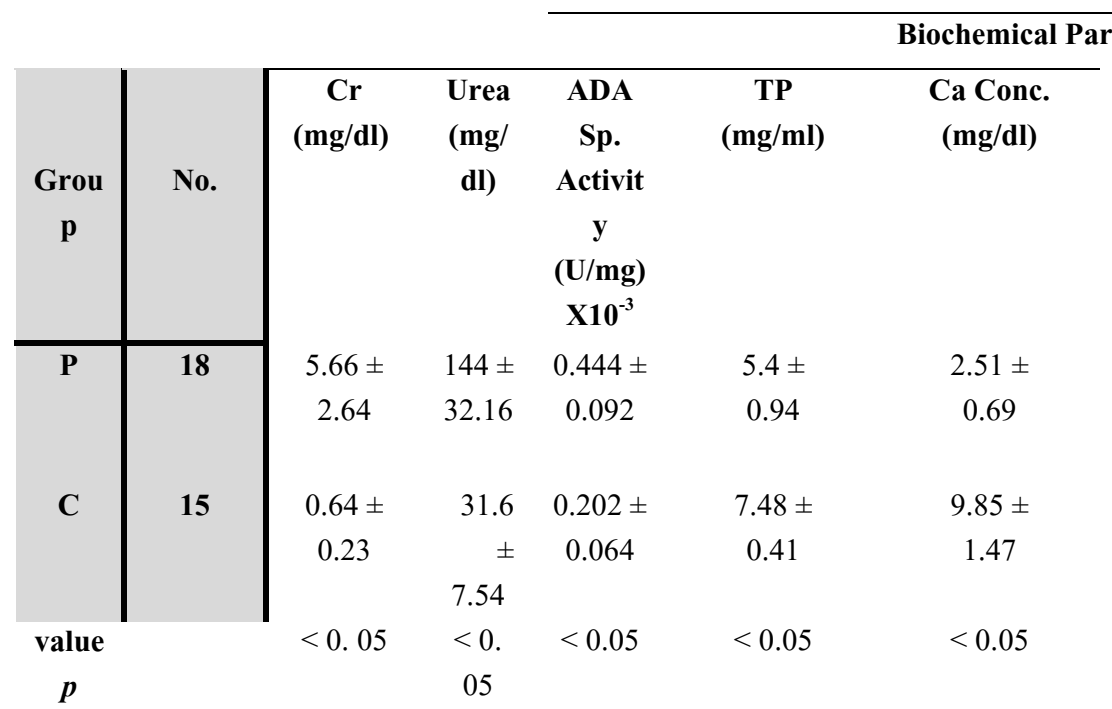

Data were expressed in mean $\pm S D$ and analyzed by t-test via Microsoft Excel 2010.

P: Patients group, C: Control group, Cr: Creatinin, TP: Total protein, ADA: Adenosine deaminase, Ca: Calcium, SD: standard deviation.

Serum urea and $\mathrm{Cr}$ tests are routine tools in the diagnosis and follow-up of CKD treatment. Urea, one of the by-products of protein catabolism, which its serum concentration increases in the blood in kidney diseases causes uremia, on the other hand, $\mathrm{Cr}$ is produced in the muscles by the non-enzymatic changes of creatine and phosphocreatinine [4]. The results show significant 


\section{University of Thi-Qar Journal Vol.12 No.4 DEC 2017 \\ Web Site: https://jutq.utq.edu.iq/index.php/main \\ Email: journal@jutq.utq.edu.iq}

$(\mathrm{P}<0.05)$ increase in both urea and $\mathrm{Cr}$ concentrations in patients group when compared with those of the control group.

These results had become axiom in the literatures $[3,14]$. In CRF, the increased serum urea level is proportional to the progression of the disease, but it is highly influenced by a catabolic state or an excessive protein ingestion, leading to a higher production of other waste substances of protein catabolism while the increase in Cr level in the serum of patients with CRF is attributed to the decrease in the number of functioning nephrons $[12,14]$.

The mean value of ADA specific activity for the patients group $(0.444 \mathrm{X}$ $10^{-3} \mathrm{U} / \mathrm{mg}$ ) was significantly higher $(\mathrm{p}<0.05)$ than that of control group $\left(0.202 \times 10^{-3} \mathrm{U} / \mathrm{mg}\right)$.

The results are agree with Dussol et al, 2004 who found that mononuclear adenosine deaminase (MCADA) activity insignificantly increases in CKD patients before the first hemodialysis session [15]. In addition, Marleswki et al., 2000 observed that accelerated degradation of adenosine was much faster in erythrocytes of CKD patients than in cells of healthy volunteers, which means, there is increased activity of adenosine hydrolytic enzyme ADA [16].

The results were conflicted with Kadhim et al, 2010 who found that ADA activity was decreased significantly in group of patients with CRF compared to control group [17]. Also, Chielle et al, 2015 noticed a significant increase in ADA activity in post-dialysis patients when compared with pre-dialysis for the same patients [3].

As mentioned earlier, few previous studies which interested ADA in renal failure patients and it is worth to be mentioned that different methodologies were used for measurement of the ADA activity. Hence, some findings may be conflicted. Here, we used a highly sensitive and specific method for ADA determination. 


\section{University of Thi-Qar Journal Vol.12 No.4 DEC 2017 \\ Web Site: https://jutq.utq.edu.iq/index.php/main \\ Email: journal@jutq.utq.edu.iq}

In renal diseases, blood volume is increased. Of this, higher blood volume results in a large amounts of lymphocytes and monocytes which has a highest ADA activity [18,3]. ADA2 isoenzyme is more abundant in human plasma than in ADA1. But in the same time, it has an extremely low ADA activity at physiological concentrations of substrate where the rate of adenosine deamination catalyzed by ADA2 is close to zero at this conditions. This may what explain decreased ADA activity in control group comprised the patients group.

Renal failure refers to a condition where the kidneys lose their normal functionality, which may be due to various factors including infections, auto immune diseases [2]. The reasons for these finding can be speculated that the stage of the disease and the immune response of the host may have a positive influence in the release of ADA from the tissue cells [7]. As a marker of cellular immunity, plasma ADA activity is found to be elevated in those diseases in which there is a cell-mediated immunity [13].

The enzyme levels of plasma may be caused by the rate of its release in plasma and/or the rate of its clearance from plasma. Increased due to proliferation of cells which produce relevant enzyme, an increase in the rate of cell turnover or damage resulting in leakage of enzyme or in enzyme synthesis (induction), or to reduced clearance from plasma [19].

The mean value of calcium concentration for the patients group was significantly lower $(p<0.05)$ than that of control group. The results were agree with previous studies where found that serum calcium was lower due to that the kidneys are in part responsible for the conversion of vitamin D to its active metabolite, which is important in the absorption of calcium from the intestine, so in renal failure patients most kidneys were failed, so this make lowering vitamin $\mathrm{D}[14,20]$.

\section{A}


University of Thi-Qar Journal Vol.12 No.4 DEC 2017

Web Site: https://jutq.utq.edu.iq/index.php/main

Email: journal@jutq.utq.edu.iq

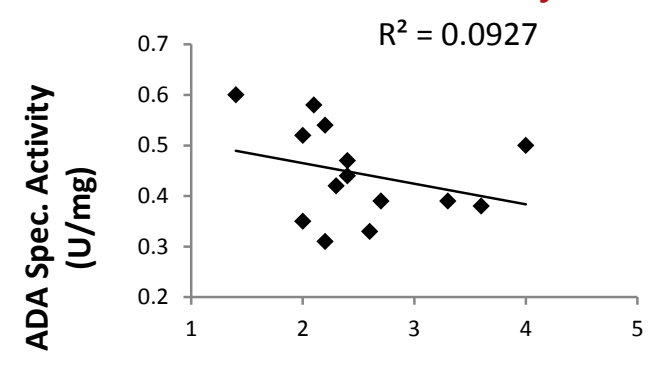

...Calcium Conc. (mg/dl)

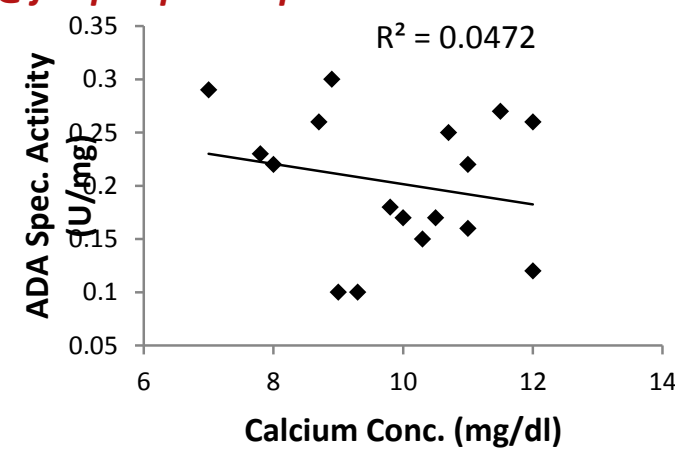

Figure1: The correlation between serum ADA specific activity (U/mg) and calcium concentration $(\mathrm{mg} / \mathrm{ml})$.
A: Patients group.
B: control group.

Among the aims of this work was to compare the enzyme activity with calcium concentration in order to check the possibility of using it as an early diagnosis tool for this disease.

A correlation curve was plotted between ADA specific activities with calcium concentrations for two studied groups. From the results in figure $1 \mathrm{~A}$ and $\mathbf{B}$, it is clear that there was very weak negative correlation $(r=-0.0927)$ and $(\mathrm{r}=-0.0472)$ in patients with renal failure and control samples respectively.

Our study showed for the first time a correlation between ADA activity and calcium concentration in patients with renal failure. We did not find available data in the literature explaining the reason for that. Calcium is the one of set of inhibitors ions which diminish the ADA activity [21]. Mohammad, 2012 concluded that decreased calcium concentration may be one of factors participate in elevated ADA activity when he studied the activity and properties of ADA in patients tissues of benign and malignant colon tumors [22]. However, wider and more specific studies are needed to 


\section{University of Thi-Qar Journal Vol.12 No.4 DEC 2017 \\ Web Site: https://jutq.utq.edu.iq/index.php/main \\ Email: journal@jutq.utq.edu.iq}

show the effectiveness of serum ADA activity as in patients with chronic kidney disease.

\section{References}

[1] www.thiqarhealth.iq.org

[2] Merzah K. S, Hasson S. F. The Biochemical Changes in Patients with Chronic Renal Failure. Inter J Pharm Med and Biol Sci. 2015, Vol. 4, No.1.

[3] Chielle E. O.; Kaue A. R.; Idania A. A.; Vanessa S.; Gelson A. D. Influence of hemodialysis on the plasma concentration of adenosine deaminase in patients with chronic kidney disease. J Bras Patol Med Lab. 2015, Vol. 51, No.3.

[4] Amin N.U, Mahmood R.T, Asad M.J, Zafar M, and Raja A.M. Evaluating Urea and Creatinine Levels in Chronic Renal Failure Pre and Post Dialysis: A Prospective Study. J Cardiovas Dis. 2014, Vol.2 No.2.

[5] Mohammad D.K.. Effect of Hemodialysis and Peritoneal Dialysis on some Hematological and Biochemical Parameters in Renal Failure. Zanco J Med Sci. 2009, Vol. 13, No. 2.

[6] Kadhim S.H, Mahdi S.A, Al.Gazally M.E. Study of Some Purine Metabolic Enzymes in Sera of Patients with Renal Failure. Med J Babyl. 2010, Vol. 7, No. $1-2$.

[7] AL-Shammaree S. A. Some Biochemical Aspects in Women Patients with Benign and Malignant Cervix and Uterine Tumors. PhD Thesis, College of Science, University of Baghdad. 2002.

[8] Maiuolo J, Oppedisano F, Gratteri S, Muscoli C, Mollace V. Regulation of uric acid metabolism and excretion. Inter J Cardiol. 2016, Vol. 213: 8-14.

[9] Michael R. Blackburn,a Jonathan B. Volmer,a Janci L. Thrasher,a Hongyan Zhong,a Jeff R. Crosby,b James J. Lee,b and Rodney E. Kellemsa. Metabolic Consequences of Adenosine Deaminase Deficiency in Mice Are Associated with Defects in Alveogenesis, Pulmonary Inflammation, and Airway Obstruction. $J$ Exp Med. 2000 Jul 17; Vol. 192, No.2: 159-170.

[10] Gülseren D., Pinar B., Figen A., Tuba ., Ferda K. and Gulsen Y. Serum Adenosine Deaminase Level is High But Not Related with Disease Activity 


\section{University of Thi-Qar Journal Vol.12 No.4 DEC 2017 \\ Web Site: https://jutq.utq.edu.iq/index.php/main Email: journal@jutq.utq.edu.iq}

Parameters in Patients with Rheumatoid Arthritis. The Open Rheumato J. 2014, 8, 24-28.

[11] Goodarzi MT, Abdi M, Tavilani H, Nadi E, Rashidi M. Adenosine deaminase activity in COPD patients and healthy subjects. Iran J Allergy Asthma Immunol. 2010 Mar; Vol. 9, No.1:7-12.

[12] Bishop M, Fody E. and Schoeff L. Clinical chemistry, 5th ed. Lippincott's Williams \& wilkins, USA, 2005.

[13] AL-Khafaji H.A, AL-Jeboori T.I. and Juma A.S. Serum Adenosine Deaminase Level in Iraqi Women with Toxoplasmosis with a History of Abortion. Amer $J$ Microb. 2016, Vol. 7, No.1:12-17.

[14] Jumaah I. A. A study of some biochemical parameters in blood serum of patients with chronic renal failure. J Bas Res (Sciences), 2013, Vol. 39, No. 4.

[15] Dussol B, Fenouillet E, Brunet P, Purgus R, Sauze N, Carrega L, Mercier L, Zouher I, Bechis G, Berland Y,and Guieu R. Kinetic study of adenosine concentrations and the expression of adenosine deaminase in mononuclear cells during hemodialysis. Kidney Int. 2004, Vol. 66, No.4: 1640-6.

[16] Marlewski M, Smolenski RT, Szolkiewicz M, Aleksandro Wicz Z, Rutkowski B, Swierczynski J. Accelerated degradation of adenine nucleotide in erythrocytes of patients with chronic renal failure. Mol Cell Biochem. 2000; Vol. 213, No.1-2: 93-7.

[17] Kadhim S.H, Mahdi S.A, Al.Gazally M.E. Study of Some Purine Metabolic Enzymes in Sera of Patients with Renal Failure. Med J Babylon, 2010,Vol.7, No.1.

[18] A collaborative approach. Chronic Kidney Disease (CKD). Divisions of nephrology \& hypertension and general internal medicine. Ed. 6, Henry Ford health system. USA. 2011.

[19] Trotta P.P.Identification of a membrane adenosine deaminase binding protein from human placenta. Biochem. 1982; No.21: 4014-4023.

[20] Mohammad D. K. Effect of Hemodialysis and Peritoneal Dialysis on some Hematological and Biochemical Parameters in Renal Failure. Zanco J Med Sci. 2009,Vol.13, No.2. 


\section{University of Thi-Qar Journal Vol.12 No.4 DEC 2017 \\ Web Site: https://jutq.utq.edu.iq/index.php/main \\ Email: journal@jutq.utq.edu.iq}

[21] Jooly P, Kelley W, Orkin S. Adenosine Deaminase Inhibitors. J Med Chem. 2005, No.118: 428-431.

[22] Mohammad F. A. Isolation and studying the activity and properties of ADA in patients tissues of benign and malignant colon tumors. Raf J Sci. 2012,Vol.23, No.2: 117-130.

علاقة فعالية الانزيم ادينوسين دي امينيز مع تركيز الكالسيوم في مصل الام لمرضى الفشل الكلوي

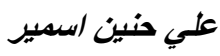

قسم الكيمياء/كلية العلوم/جامعة ذي قار

الخلاصة

يعتبر مرض الفشل الكلوي المزمن من اكثر المشاكل الصحية شيوعا في العراق. كان الهدف من هذا العمل هو لتتخيص فيما اذا كان هنالك ثمة علاقة بين فعالية انزيم الادينوسين دي امينيز مع الكالسيوم الموجود في دم المرضى المصابين بمرض الفشل الكلوي الحاد وللمرة الاولى لهلي ثم استخدام تلك العلاقة كمعيار او اداة في تتخيص المرض. تم قياس عدة معايير كيموحيوية مثل فيل الكرياتينين،اليوريا، تركيز البروتين الكلي اضافة الى قياس فعالية الانزيم (ADA) وتركيز الكالسيوم لثلاثة وثلاثين شخصا من الذكور قسمو الى مجمو عتين الاولى ضمت (18) مريضا مصاب بالفشل الكلوي الراقدين في مستشفى الحسين التعليمي قبيل اجرائهم غسيل الكلى (الديلزة)، بينما كانت المجموعة الثانية وهي مجموعة السيطرة وضمت (15) شخصا سليما. انشارت النتائج الو وجود زيادة معنوية في تركيز الكرياتينين و اليوريا اضافة الى فعالية الانزيم (ADA) ،بينما كان هناك نقصا معنويا في نركيز كل من البروتين الكلي والكالسيوم في مصل الدم لمجموعة المرضى مقارنة بمجموعة السيطرة. كان هناك ثمة ارتباط سلبي ضعيف بين فعالية الانزيم (ADA ) وتركيز

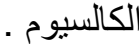

